\title{
Are there national strategies, plans and guidelines for the treatment of hepatitis $C$ in people who inject drugs? A survey of 33 European countries
}

\author{
Mojca Maticic ${ }^{1 *}$, Jerneja Videcnik Zorman ${ }^{1}$, Sergeja Gregorcic ${ }^{1}$, Eberhard Schatz ${ }^{2}$, Jeffrey $V$ Lazarus ${ }^{3}$
}

\begin{abstract}
Background: Hepatitis C virus (HCV) infection represents a major global health problem, which in high-income countries now mostly affects people who inject drugs (PWID). Many studies show that the treatment of HCV infection is as successful among PWID as among other populations and recently PWID have been included in the international guidelines for the treatment of HCV infection. The aim of this survey was to collect data from European countries on the existence of national strategies, action plans and clinical guidelines for HCV treatment in the general population and PWID in particular.

Methods: Thirty-three European countries were invited to participate. Data on available national strategies, action plans and guidelines for HCV treatment in the general population and in PWID specifically were collected prospectively by means of a structured electronic questionnaire and analyzed accordingly.

Results: All of the 33 invited European countries participated in the survey. Twenty-two responses came from nongovernmental organizations, six from public health institutions, four from university institutions and one was an independent consultant. Fourteen (42.4\%) of the countries reported having a national strategy and/or national action plan for HCV treatment, from which ten of them also reported having a national strategy and/or national action plan for treatment of HCV infection in PWID. Nearly three-quarters reported having national HCV treatment guidelines. PWID were included in the majority (66.7\%) of the guidelines. Fourteen (42.4\%) countries reported having separate guidelines for the treatment of HCV infection in PWID.

Conclusions: Given the high burden of HCV-related morbidity and mortality in PWID in Europe, the management of HCV infection should become a healthcare priority in all European countries, starting with developing or using already-existing national strategies, action plans and guidelines for this population.
\end{abstract}

\section{Introduction}

Hepatitis $\mathrm{C}$ virus (HCV) imposes a considerable disease burden worldwide and is one of the major underlying causes of chronic liver disease-related death [1]. Approximately $50-80 \%$ of individuals exposed to HCV develop chronic infection, and cirrhosis occurs in $10-15 \%$ of these cases within the next 20 years [2,3]. The rate of progression to cirrhosis is highly variable and is influenced by

\footnotetext{
* Correspondence: mojca.maticic@kclj.si

${ }^{1}$ Clinic for Infectious Diseases and Febrile Illnesses, University Medical Centre Ljubljana, Ljubljana, Slovenia

Full list of author information is available at the end of the article
}

several factors [3]. Persons with cirrhosis are at increased risk for developing end-stage liver disease and hepatocellular carcinoma, the sixth most common cause of cancer globally [3,4]. Chronic HCV infection remains the leading cause of liver transplantation; in 2004, one-quarter of liver transplants performed in 25 European countries were attributable to $\mathrm{HCV}[5,6]$.

It has been estimated that between 130 and 170 million people are chronically infected with $\mathrm{HCV}$ worldwide and that 350,000 deaths occur each year as a result of $\mathrm{HCV}$ [7]. A 2009 analysis of data from 22 European countries concluded that as many as nine million people in the 
focal area may be HCV-infected [4]. The World Health Organisation (WHO) HCV prevalence estimates for 32 European countries indicated higher HCV prevalence in southern and eastern Europe than in northern Europe [8]. HCV was thought to cause an estimated 86,000 deaths annually in the entire European region [9].

After it became routine to screen blood products for $\mathrm{HCV}$ in developed countries, intravenous drug use replaced blood transfusion as the main $\mathrm{HCV}$ transmission route in these countries $[9,10]$. Injecting drug use is a major public health problem around the world as almost 16 million people injected drugs in 2007 [11]. According to 2010 estimates, five million European people who inject drugs (PWID) are HCV antibody-positive, with annual incidence varying from $5 \%$ to $45 \%[11,12]$. With $50 \%$ to $80 \%$ of PWID infected in the developed world, HCV is much more prevalent than either hepatitis B virus infection or HIV in this high-risk population. Furthermore, HCV sero-prevalence is much higher in PWID than in the general population $[13,14]$.

Research indicates that $\mathrm{HCV}$ treatment outcomes for PWID are comparable to those for other patients in terms of adherence to treatment, completion of the full treatment course and attainment of a sustained viral response (SVR) $[15,16]$. Moreover, modelling studies suggest that treatment of active PWID could control the burden of $\mathrm{HCV}$ in this population by decreasing the viral load among current drug injectors and reducing transmission rates [17]. Therefore, PWID should represent one of the most important target populations for treatment. Since the cohorts of non-treated PWID with chronic hepatitis C are ageing they represent a significant proportion of patients with advanced liver disease and liver-related mortality $[18,19]$. Twenty to $25 \%$ of deaths among PWID are related to the latter [20]. Further, daily use of cannabis may be associated with advanced liver fibrosis, and heavy alcohol consumption which is commonly present in PWID is associated with a higher risk of cirrhosis [21,22]. However, many clinicians are reluctant to treat hepatitis C in PWID because of concerns regarding re-infection, serious side-effects, potential lack of adherence to treatment, high rates of concomitant alcohol abuse and mental health issues [23].

National HCV treatment strategies, action plans and clinical guidelines that recognise PWID as a distinct patient population can help foster an enabling environment in which PWID are more likely to be given equal access to treatment [24]. Little is known about the extent to which these tools and resources are in place in European countries. The aim of our study was to collect data from European countries on the existence of national $\mathrm{HCV}$ treatment strategies, action plans and clinical guidelines for both the general population and PWID.

\section{Methods}

The study was performed between September and December 2013. Data were collected by means of a structured electronic questionnaire that was sent via e-mail to individuals in 33 European countries. In the survey Scotland was treated separately from the United Kingdom and was presented as one of the participating countries due to its well-recognised autonomous system for the management of hepatitis $C$ that is covered by the Scottish National Healthcare System. The data from the United Kingdom excluded the data for Scotland. Informants were drawn from a database of contacts maintained by the Hepatitis $\mathrm{C}$ Initiative of the Correlation Network, and were selected because their work deeply involves HCV/PWID issues.

The questionnaire was prepared at the Clinic for Infectious Diseases and Febrile Illnesses, University Medical Centre Ljubljana, Slovenia. It was constructed as a nineitem survey in which answers could only be "yes" or "no" (Table 1). Respondents were asked to provide references for national guidelines on HCV treatment and had the option of adding comments to clarify their answers. The survey also requested the names, organisational affiliations and countries of respondents. The questionnaire was written in English since no language barriers were expected from survey recipients.

PWID were defined as either people who were "actively" injecting drugs, referring to those who had used drugs in the past six months, or as people who were former injectors, including those who were still active non-injection drug users and/or used opioid substitution treatment (OST). The definition was taken from recent recommendations for the management of HCV infection in PWID published by the International Network on Hepatitis in Substance Users (INHSU) [25].

Data were collected by the Hepatitis C Initiative of the Correlation Network and then were reviewed and analysed by the authors of the questionnaire.

\section{Results}

Survey responses were obtained from all targeted countries. One survey was received from each of 31 countries. For two other countries, Finland and Italy, two people submitted surveys. One respondent from Finland represented a university-based institution and the other represented a public health institution; both respondents from Italy represented nongovernmental organisations (NGOs). The two Finnish respondents provided the same answers, as did the two Italian respondents. Each set of identical submissions was combined into a single record for Finland and a single record for Italy, with the two respondents regarded as a single respondent. The Finland submission counted as a university institution since more detailed 


\begin{tabular}{lc}
\hline Does your country have a national strategy for treatment of HCV? & yes/no \\
If yes, does it include actions with regards to PWID? & yes $/$ no \\
Does your country have a national action plan for treatment of HCV (in place of or in addition to a strategy)? & yes $/$ no \\
If yes, does it include actions in regard of PWID? & yes $/$ no \\
Does your country have national guidelines for treatment of HCV? & yes/no \\
If yes, does this include guidelines in regard of PWID or are these separate guidelines in regard of PWID: & yes $/$ no \\
Guidelines in regard of PWID are included & yes $/$ no \\
Separate guidelines in regard of PWID & yes $/$ no \\
In case there are separate guidelines in regard of PWID, are they applicable to: & yes $/$ no \\
PWID on opiate substitution treatment & \\
Active PWID &
\end{tabular}

HCV: hepatitis C virus. PWID: people who inject drugs.

comments were provided by the respondent from there. Hence, the final dataset contained one record and one respondent per country for 33 countries.

Respondents reported various affiliations. About twothirds of them $(22 ; 66.7 \%)$ represented NGOs. Six (18.2\%) were based at public health institutions, four $(12.1 \%)$ were based at university institutions, and one (3\%) functioned as a freelance trainer and consultant.

The results of the survey are summarized in Table 2.

\section{National strategy for treatment of HCV infection}

Twelve countries (36.4\%) reported having a national HCV treatment strategy. All but one of them reported that PWID are included in the strategy. The remaining 21 countries $(63.6 \%)$ reported not having a national $\mathrm{HCV}$ treatment strategy.

\section{National action plan for treatment of HCV infection}

Ten countries $(30.3 \%)$ reported having a national action plan for HCV treatment. In seven of the ten countries, this plan was reported to include PWID. Respondents from two additional countries, Croatia and Finland, indicated that their countries were in the process of developing a national strategy and action plan. The respondent from Italy stated that his country was currently waiting for the government to approve a national strategy and action plan. The respondent from Austria did not answer this question.

\section{National guidelines for treatment of HCV infection}

Twenty-four countries (72.7\%) were said to have national guidelines for treatment of HCV infection. Among the nine countries that reported not having national HCV treatment guidelines, some respondents commented on guidance that was in the process of being prepared. According to the respondent from Romania, a non-governmental document that is wellrecognised and appreciated among clinicians provides guidance on treatment decisions in that country. The respondent from Finland reported that country's national guidelines to be under development. In Italy, national guidelines reportedly had been prepared but had not yet been approved by the government. Until approval is granted, clinicians are expected to follow regional guidelines since the national health service in Italy is based on regional laws. In Switzerland, an awareness campaign on HCV treatment exists for professionals on a national level; further, an analyses of the situation regarding prevention and treatment of $\mathrm{HCV}$ were being carried out by the federal authorities, with the purpose of creating guidelines for HCV treatment in the general population and PWID based on the results of the analyses.

\section{National guidelines for treatment of HCV infection in people who inject drugs}

Among the 24 countries reported to have national guidelines for HCV treatment, 20 countries were said to address HCV treatment for PWID in their guidelines. Two additional countries, Serbia and Switzerland, had contradictory information. In both cases, respondents indicated that national guidelines for HCV treatment did not exist, but that PWID were included in the guidelines. Fourteen of the 33 countries (42.4\%) were reported to have separate guidelines for the treatment of HCV in PWID; among them, 11 reported including PWID in the national guidelines for HCV treatment.

A survey question asking if there are separate guidelines for PWID who are on opiate substitution treatment (OST) received 15 "yes" responses (45.5\% of countries). Five other countries had responses of "no," and the question was not answered by respondents from the remaining countries. Nine countries $(27.3 \%)$ were reported to have separate guidelines for treatment of $\mathrm{HCV}$ infection in active drug users. Among the remaining countries, respondents from nine countries indicated that there were not separate guidelines; no answer was provided in the other cases. 
Table 2 Survey results

\begin{tabular}{|c|c|c|c|c|c|c|c|}
\hline Country* & $\begin{array}{c}\text { National } \\
\text { strategy for } \\
\text { HCV treatment } \\
\text { / PWID } \\
\text { included }\end{array}$ & $\begin{array}{l}\text { National action } \\
\text { plan for HCV } \\
\text { treatment / } \\
\text { PWID included }\end{array}$ & $\begin{array}{c}\text { National } \\
\text { HCV } \\
\text { treatment } \\
\text { guidelines }\end{array}$ & $\begin{array}{c}\text { National HCV } \\
\text { treatment } \\
\text { guidelines: } \\
\text { PWID } \\
\text { included }\end{array}$ & $\begin{array}{c}\text { Separate } \\
\text { national HCV } \\
\text { treatment } \\
\text { guidelines for } \\
\text { PWID }\end{array}$ & $\begin{array}{l}\text { Separate PWID } \\
\text { guidelines are } \\
\text { applicable to } \\
\text { PWID on OST }\end{array}$ & $\begin{array}{c}\text { Separate PWID } \\
\text { guidelines are } \\
\text { applicable to } \\
\text { active PWID }\end{array}$ \\
\hline $\begin{array}{c}\text { Albania } \\
N G O\end{array}$ & $\mathrm{~N} / \mathrm{N}$ & $\mathrm{Y} / \mathrm{N}$ & $Y$ & $Y$ & $\mathrm{~N}$ & $Y$ & $\mathrm{~N}$ \\
\hline $\begin{array}{c}\text { Austria } \\
N G O\end{array}$ & $Y / Y$ & na/na & Y & na & na & na & na \\
\hline$\underset{N G O}{\text { Belgium }}[26]$ & $\mathrm{N} / \mathrm{N}$ & $\mathrm{N} / \mathrm{N}$ & $N$ & N & na & na & na \\
\hline $\begin{array}{c}\text { Bosnia and } \\
\text { Herzegovina [27] } \\
\text { University }\end{array}$ & $Y / Y$ & $Y / Y$ & $Y$ & $Y$ & $\mathrm{~N}$ & na & na \\
\hline $\begin{array}{c}\text { Bulgaria } \\
\text { Public health }\end{array}$ & $\mathrm{N} / \mathrm{na}$ & $\mathrm{Y} / \mathrm{N}$ & Y & na & Y & na & na \\
\hline $\begin{array}{c}\text { Croatia } \\
N G O\end{array}$ & N/na & N/na & Y & Y & na & na & na \\
\hline $\begin{array}{l}\text { Czech Republic [28-30] } \\
\text { University } \\
\end{array}$ & $\mathrm{N} / \mathrm{N}$ & $\mathrm{N} / \mathrm{N}$ & Y & N & Y & Y & Y \\
\hline $\begin{array}{c}\text { Denmark }[31,32] \\
\text { Public health }\end{array}$ & $Y / Y$ & $Y / Y$ & Y & $Y$ & $Y$ & na & $Y$ \\
\hline $\begin{array}{l}\text { Estonia [33] } \\
\quad N G O\end{array}$ & $\mathrm{~N} / \mathrm{N}$ & $\mathrm{N} / \mathrm{N}$ & $\mathrm{N}$ & $\mathrm{N}$ & $\mathrm{N}$ & $\mathrm{N}$ & $\mathrm{N}$ \\
\hline $\begin{array}{l}\text { Finland [34] } \\
\quad N G O\end{array}$ & $\mathrm{~N} / \mathrm{N}$ & $\mathrm{N} / \mathrm{N}$ & $\mathrm{N}$ & $\mathrm{N}$ & $\mathrm{N}$ & $\mathrm{N}$ & $\mathrm{N}$ \\
\hline $\begin{array}{c}\text { France }[35,36] \\
N G O\end{array}$ & $Y / Y$ & $Y / Y$ & Y & $Y$ & $N$ & na & na \\
\hline $\begin{array}{c}\text { Germany }[37,38] \\
N G O\end{array}$ & $\mathrm{~N} / \mathrm{N}$ & $\mathrm{N} / \mathrm{N}$ & Y & $Y$ & $\mathrm{~N}$ & na & na \\
\hline $\begin{array}{l}\text { Greece [39] } \\
\text { Public health }\end{array}$ & $Y / Y$ & $Y / Y$ & Y & Y & Y & Y & $N$ \\
\hline $\begin{array}{l}\text { Hungary [40] } \\
\text { NGO }\end{array}$ & $\mathrm{N} / \mathrm{N}$ & $\mathrm{N} / \mathrm{N}$ & $Y$ & $Y$ & Y & $Y$ & $Y$ \\
\hline $\begin{array}{l}\text { Ireland [41] } \\
\qquad N G O\end{array}$ & $Y / Y$ & $\mathrm{Y} / \mathrm{N}$ & Y & $\mathrm{N}$ & Y & $Y$ & na \\
\hline $\begin{array}{c}\text { Italy }[42,43] \\
\quad N G O\end{array}$ & $\mathrm{~N} / \mathrm{N}$ & $\mathrm{N} / \mathrm{N}$ & $\mathrm{N}$ & $\mathrm{N}$ & $N$ & $N$ & $N$ \\
\hline $\begin{array}{l}\text { Latvia [44] } \\
\quad N G O\end{array}$ & $\mathrm{Y} / \mathrm{N}$ & $\mathrm{N} / \mathrm{N}$ & Y & $Y$ & Y & $Y$ & $N$ \\
\hline $\begin{array}{c}\text { Lithuania [45] } \\
\text { University }\end{array}$ & $Y / Y$ & $\mathrm{~N} / \mathrm{N}$ & $Y$ & $Y$ & Y & $Y$ & $Y$ \\
\hline $\begin{array}{l}\text { Macedonia } \\
\quad N G O\end{array}$ & $\mathrm{~N} / \mathrm{N}$ & N/na & Y & Y & Y & Y & Y \\
\hline $\begin{array}{c}\text { Montenegro } \\
\text { NGO }\end{array}$ & $\mathrm{N} / \mathrm{N}$ & $\mathrm{N} / \mathrm{N}$ & $\mathrm{N}$ & $N$ & $\mathrm{~N}$ & $\mathrm{~N}$ & $\mathrm{~N}$ \\
\hline $\begin{array}{c}\text { Norway } \\
N G O\end{array}$ & $Y / Y$ & $\mathrm{~N} / \mathrm{N}$ & $Y$ & $Y$ & 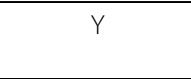 & na & $Y$ \\
\hline $\begin{array}{l}\text { Poland [46] } \\
\quad N G O\end{array}$ & $\mathrm{~N} / \mathrm{N}$ & $\mathrm{N} / \mathrm{N}$ & $\bar{Y}$ & 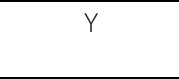 & $\mathrm{N}$ & 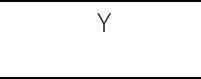 & na \\
\hline $\begin{array}{c}\text { Portugal } \\
N G O\end{array}$ & $\mathrm{~N} / \mathrm{N}$ & $\mathrm{N} / \mathrm{N}$ & Y & $Y$ & $\mathrm{~N}$ & na & na \\
\hline $\begin{array}{c}\text { Romania [47] } \\
N G O\end{array}$ & $\mathrm{~N} / \mathrm{N}$ & $\mathrm{N} / \mathrm{N}$ & $\mathrm{N}$ & na & na & $Y$ & na \\
\hline $\begin{array}{l}\text { Scotland [48] } \\
\text { Public health }\end{array}$ & $Y / Y$ & $Y / Y$ & $Y$ & $Y$ & $Y$ & $Y$ & $Y$ \\
\hline $\begin{array}{l}\text { Serbia } \\
N G O\end{array}$ & $\mathrm{~N} / \mathrm{N}$ & $\mathrm{N} / \mathrm{N}$ & $\mathrm{N}$ & $Y$ & na & na & $Y$ \\
\hline
\end{tabular}


Table 2 Survey results (Continued)

\begin{tabular}{|c|c|c|c|c|c|c|c|}
\hline $\begin{array}{c}\text { Slovakia [49] } \\
\text { NGO }\end{array}$ & $\mathrm{N} / \mathrm{N}$ & $\mathrm{N} / \mathrm{N}$ & $Y$ & $Y$ & $Y$ & na & na \\
\hline $\begin{array}{c}\text { Slovenia }[50,51] \\
\text { University }\end{array}$ & $\mathrm{Y} / \mathrm{Y}$ & $Y / Y$ & $Y$ & $Y$ & $Y$ & $Y$ & $Y$ \\
\hline $\begin{array}{c}\text { Spain [52] } \\
\text { Public health }\end{array}$ & $\mathrm{N} / \mathrm{N}$ & $\mathrm{N} / \mathrm{N}$ & $Y$ & $Y$ & $\mathrm{~N}$ & $Y$ & $\mathrm{~N}$ \\
\hline $\begin{array}{l}\text { Sweden } \\
N G O\end{array}$ & $\mathrm{~N} / \mathrm{N}$ & $\mathrm{N} / \mathrm{N}$ & $N$ & $N$ & $\mathrm{~N}$ & $N$ & $N$ \\
\hline $\begin{array}{l}\text { Switzerland } \\
\text { Public health }\end{array}$ & $\mathrm{N} / \mathrm{N}$ & $\mathrm{N} / \mathrm{N}$ & $N$ & $Y$ & na & $Y$ & na \\
\hline $\begin{array}{l}\text { The Netherlands [53-55] } \\
\text { NGO }\end{array}$ & $\mathrm{N} / \mathrm{N}$ & $\mathrm{N} / \mathrm{N}$ & $Y$ & $Y$ & $Y$ & $Y$ & na \\
\hline $\begin{array}{l}\text { United Kingdom [56-58] } \\
\text { Freelance trainer/ } \\
\text { consultant }\end{array}$ & $Y / Y$ & $Y / Y$ & $Y$ & $Y$ & $N$ & na & na \\
\hline
\end{tabular}

*If respondents provided references to national guidelines, the citations are given in brackets following country names. All respondent affiliations are indicated in italics following country names.

N: no. Y: yes. na: no answer. NGO: non-governmental organization. HCV: hepatitis C virus. PWID: people who inject drugs. OST: opioid substitution treatment.

\section{Discussion}

During the last two decades, it appears that low HCV treatment uptake among PWID in developed countries has contributed to high levels of advanced liver disease and liver disease-related mortality, with $20-25 \%$ of deaths in this population attributable to liver disease [59-61]. In general, not accessing $\mathrm{HCV}$ treatment has been associated with several barriers arising mostly from poor knowledge and inaccurate perceptions about HCV [62].

Seven respondents involved in this survey (Denmark, France, Greece, Ireland, Scotland, Slovenia and the United Kingdom excluding Scotland) reported having both a national strategy and a national action plan for treatment of HCV infection that also include actions in regard of PWID. They also reported on having national guidelines for treatment of HCV infection and separate guidelines for treatment of HCV-infected PWID. In all of these countries, apart from Denmark, there have been several studies on HCV treatment access in PWID. The proportion of treated PWID reached $40 \%$ in a French study and $57 \%$ in a Greek study $[63,64]$. In Slovenia, the proportion of PWID treated for $\mathrm{HCV}$ increased from $3 \%$ to $13 \%$ in the first three years after the 2007 introduction of the national strategy, action plan and clinical guidelines; $72 \%$ of all the newly treated patients in the period 2008-2010 reported a history of drug use [64]. As for Scotland, the clinical services that were developed with the implementation of the Hepatitis $C$ Action Plan led to a doubling in the number of those who initiated therapy in the years 2010-2011 compared to the period before the 2006 introduction of the plan. Eighty percent of people initiating HCV treatment in 2010-2011 had a history of injecting drugs [65]. These observations support the premise that the national policy context is a crucial factor in determining how much PWID will be able to benefit from HCV treatment interventions. To systematically address the barriers to treatment, several steps could be undertaken, with three essential steps being the establishment of a national strategy, action plan and clinical guidelines on $\mathrm{HCV}$ treatment.

Although ever/current drug injectors have treatment efficacy and safety outcomes that are comparable to those for people with no history of drug use [15,66-70], and successful treatment could reduce the likelihood of HCV transmission among PWID by eliminating potential sources of infection [9], international and national treatment guidelines historically have excluded PWID, particularly current injectors, from being treated for hepatitis $C[15,70,71]$. In 2011, however, the Clinical Practice Guidelines of the European Association for the Study of the Liver (EASL) were revised to endorse the provision of HCV treatment to certain PWID based on an individual approach [72]. The 2014 update to these guidelines goes even further in terms of considering substance users as a treatable patient group at risk provided they wish to receive treatment and are willing and able to maintain follow-up visits [62].

It is well recognised that the extremely varied political, economic and social circumstances of different European countries lead to very different health needs and health outcomes at the national level [73]. Furthermore, HCV infection shows great diversity among European countries, not only in its prevalence in the general population and among PWID [8,12], but also in the treatment of hepatitis C. Treatment funding, availability of anti-HCV drugs and the settings for HCV treatment in PWID vary immensely among the European countries. Policies, strategies and guidelines for HCV management therefore must be tailored to the specific national or sub-national context [73].

Several studies have shown that compared to other wellaccepted medical interventions, HCV treatment is costeffective [7]. According to the 2013 Global Policy Report 
on the Prevention and Control of Viral Hepatitis in WHO Member States, publicly funded treatment for $\mathrm{HCV}$ is available in 34 out of 44 Member States from the European Region that responded [73]. Among the participating Member States that were also included in our study, all, except Switzerland, have publicly funded HCV treatment; the data for Albania and Slovakia were not available. Norway, Portugal, Romania, Greece and Scotland, which were included in our study, did not participate in the WHO survey. Among 25 countries of our survey that also provided WHO data on funding, 14 of them reported to have treatment guidelines that include PWID, whereas only eight countries reported on having a national strategy.

Interestingly, in Latvia, which reported having a national strategy and treatment guidelines that include PWID, only $75 \%$ of the total treatment cost is publicly funded [73]. In Finland, which according to our survey is in the process of developing a national strategy and action plan for $\mathrm{HCV}$ treatment, active injecting drug use is an absolute contraindication for publicly funded HCV treatment [73]. According to the results of our study, only $27 \%$ of the respondents reported having separate guidelines for $\mathrm{HCV}$ treatment in active drug users; however, this treatment is publicly funded [73]. Switzerland provides no public funding as well as no national strategy and guidelines. As for Scotland, which is regarded globally as a model of good practice, the government made a serious financial investment to support the 2006 launch and subsequent implementation of the Hepatitis C Action Plan, with a special focus on PWID [74].

According to the 2013 WHO Global Policy Report, only $38.6 \%$ of Member States in the European region reported having boceprevir and telaprevir on national essential medicine lists or subsidised by governments [73]. It is of special concern that even pegylated interferon was reported not to be present in $20.5 \%$ of countries, or ribavirin in $13.6 \%$ of countries. In the last year, HCV treatment success and safety have advanced tremendously thanks to new treatment options. Unfortunately, the extremely high prices of the new direct acting antivirals (DDAs) will limit their availability in many European countries $[75,76]$. Therefore, national strategies and action plans might turn out to be crucial in promoting access to the new drugs. However, it is worth mentioning that no studies of DAAs have been performed in PWID populations thus far. Even the studies of boceprevir and telaprevir have excluded PWID other than OST patients, which means that no efficacy and safety data exist for this population [62].

Beside the treatment of HCV, medical health interventions for PWID also include various programmes for the management of drug addiction, including OST, which has been shown to facilitate $\mathrm{HCV}$ treatment and reduce $\mathrm{HCV}$ acquisition among PWID [15]. It is of special concern that some European countries are reluctant to use OST [77]. However, almost half of the countries involved in this study reported on having separate guidelines for $\mathrm{HCV}$ treatment in PWID on OST. Already existing settings for the management of drug use and for the treatment of HCV infection in PWID vary immensely among the European countries. Therefore, various models have been proposed for HCV treatment in PWID to be performed inter-disciplinarily in either community-based clinics, drug treatment settings, viral hepatitis clinics/hospitals or being integrated into the primary/secondary/tertiary medical setting [78]. The EASL Clinical Practice Guidelines also call for the treatment of HCV in PWID to be undertaken using a multidisciplinary approach [62]. Countries should decide on the most appropriate model for their local facilities. Slovenia provides an example of a multidisciplinary model of good practice that was introduced through a national strategy, action plan and clinical guidelines. The Slovenian model called for the integration of 18 existing drug treatment centres and five viral hepatitis centres into a national healthcare network for $\mathrm{HCV}$ treatment in PWID [50].

There are some limitations to our study. The informants who participated in the survey were selected from the database of the Correlation Network's Hepatitis C Initiative, and all of them were deeply involved in the field of PWID/HCV infection, most as representatives of non-governmental organizations. In all but two countries, only one person was approached to participate in the survey. The validity of the data was not checked separately. The data capture method of the study allows a potential bias since the organizations with strong motivations, but not necessarily linked to government policy input, can have a differing view and/or experiences to what is a current official policy. Therefore, an exploration of civil society versus political leaders/government replies from European countries on the existence of national strategies, action plans and clinical guidelines for HCV treatment in the general population and PWID in particular might be a matter for further research.

\section{Conclusions}

To the best of our knowledge this is the first study to present data on the existence of national strategies, action plans and guidelines on HCV treatment in 33 European countries, and to present data of this nature relating specifically to PWID.

The results of the survey provide data on how European countries address the problem of $\mathrm{HCV}$ treatment in PWID and try to achieve hepatitis $C$ policy objectives with regards to treatment. The survey results highlight major gaps that should be addressed in order to improve hepatitis $C$ treatment at the national level, 
particularly among PWID. Given the burden of HCVrelated morbidity and mortality in this at-risk population, the management of $\mathrm{HCV}$ infection in PWID should become a healthcare priority in all European countries. Our data demonstrate some awareness of the threat that $\mathrm{HCV}$ poses to PWID in Europe and indicate that decision-makers in some countries are willing to consider this subgroup of $\mathrm{HCV}$ patients for treatment. With several new direct acting antivirals on the horizon, there is hope that HCV infection can be cured in the majority of patients in the nearest future. However, the most highly potent regimens may remain under-utilised until the group at greatest risk for HCV infection is recognized as urgently needing access to this treatment.

\section{Competing interests}

The authors declare that they have no competing interests regarding this manuscript.

\section{Authors' contributions}

MM carried out the conceptualisation, design, and coordination of the study, drafted the manuscript and prepared the final manuscript. JVZ and SG performed the study analysis and assisted with drafting the manuscript. ES prepared the database of respondents and carried out the collection of data. JVL provided considerable input during the drafting and finalization of the manuscript. All authors read and approved the final manuscript.

\section{Declarations}

This article has been published as part of BMC Infectious Diseases Volume 14 Supplement 6, 2014: Viral Hepatitis in Europe. The full contents of the supplement are available online at http://www.biomedcentral.com/ bmcinfectdis/supplements/14/S6. The publication charges for this supplement were funded by AbbVie as an unrestricted grant to Rigshospitalet, the University of Copenhagen. AbbVie further funded the printing of the supplement with additional financial support from the Drug Prevention and Information Programme (DPIP) of the European Union.

\section{Authors' details}

${ }^{1}$ Clinic for Infectious Diseases and Febrile IIInesses, University Medical Centre Ljubljana, Ljubljana, Slovenia. ${ }^{2}$ Correlation Network, Foundation De Regenbook Groep, Amsterdam, The Netherlands. ${ }^{3} \mathrm{CHIP}$, Centre for Health and Infectious Disease Research and WHO Collaborating Centre on HIV and Viral Hepatitis, Rigshospitalet, University of Copenhagen, Copenhagen, Denmark.

\section{Published: 19 September 2014}

\section{References}

1. Lozano R, Naghavi M, Foreman $\mathrm{K}$, et al: Global and regional mortality from 235 causes of death for 20 age groups in 1990 and 2010: a systematic analysis for the Global Burden of Disease Study 2010. Lancet 2012, 380:2095-2128.

2. Kamal SM: Acute hepatitis C: a systematic review. Am J Gastroenterol 2008 , 103:1283-1297.

3. Chen SL, Morgan TR: The Natural History of Hepatitis C Virus (HCV) Infection. Int J Med Sci 2006, 3:47-52.

4. van Meer S, de Man RA, Siersema PD, Erpecum KJ: Surveillance for hepatocellular carcinoma in chronic liver disease: Evidence and controversies. World J Gastroenterol 2013, 19:6744-6756.

5. Mühlberger N, Schwarzer R, Lettmeier B, Sroczynski G, Zeuzem S, Siebert U: $\mathrm{HCV}$-related burden of disease in Europe: a systematic assesement of incidence, prevalence, morbidity and mortality. BMC Public Health 2009, 22:34-42.

6. Terrault N: Liver transplantation in the setting of chronic HCV. Best Pract Res Clin Gastroenterol 2012, 26:531-548.
7. Lavanchy D: The global burden of hepatitis C. Liver Int 2009, 29:74-81.

8. World Health Organization: Hepatitis C - global prevalence (update). Wkly Epidemiol Rec 2000, 75:18-19.

9. Hatzakis A, Wait S, Bruix J, Buti M, Carballo M, Cavaleri M, Colombo M, Delarocque-Astagneau E, Dusheiko G, Esmat G, Esteban R, Goldberg D, Gore C, Lok AS, Manns M, Marcellin P, Papatheodoridis G, Petrle A, Prati D, Piorkowsky N, Rizzetto M, Roudot-Thoraval F, Soriano V, Thomas HC, Thursz M, Valla D, van Damme P, Veldhuijzen IK, Wedemeyer H, Wiesing L: The state of hepatitis $B$ and $C$ in Europe: report from the hepatitis $B$ and C summit conference. J Viral Hepat 2011, 18(Suppl 1):1-16.

10. Esteban J, Sauleda S, Quer J: The changing epidemiology of hepatitis C virus infection in Europe. $J$ Hepatol 2008, 48:148-162.

11. Degenhardt $L$, Hall $L$ : Extent of illict drug use and dependence, and their contribution to the global burden of disease. Lancet 2012, 379:55-70.

12. Mehta SH, Astemborski J, Kirk GD, Strathdee SA, Nelson KE, Vlahov D, Thomas DL: Changes in blood-borne infection risk among injection drug users. J Infect Dis 2011, 203:587-594.

13. Wiessing L, Guarita B, Giraudon I, Brummer-Korvenkontio H, Salminen M, Cowan SA: European monitoring of notifications of hepatitis $C$ in the general population and among injecting drug users - the need to improve quality and comparability. Eurosurveillance 2008, 13:1-5.

14. Hagan H, Snyder N, Hough E, Yu T, McKeirnan S, Boase J, Duchin J: Casereporting of acute hepatitis $B$ and $C$ among injection drug users. J Urban Health 2002, 79:579-585.

15. Hellard M, Sacks-Davis R, Gold J: Hepatitis C treatment for injection drug users: a review of the available evidence. Clin Infect Dis 2009, 49:561-573.

16. Dalgaard O: Follow up studies of treatment for hepatitis $\mathrm{C}$ virus infection among injection drug users. Clin Infect Dis 2005, 40:336-338.

17. Martin NK, Vickerman P, Foster GR, Hutchinson SJ, Goldberg DJ, Hickman M: Can antiviral therapy for hepatitis $\mathrm{C}$ reduce the prevalence of HCV among injecting drug user populations? A modeling analysis of its prevention utility. J Hepatol 2011, 54:1137-1144.

18. Grebely J, Raffa JD, Lai C, Kerr T, Fischer B, Krajden M, Tyndall MF: Impact of hepatitis $C$ virus infection on all-cause and liver-related mortality in a large community-based cohort of inner city residents. J Viral Hepat 2011, 18:32-41.

19. Darke S, Kaye S, Duflou J: Comparative cardiac pathology among deaths due to cocaine toxicity, opioid toxicity and non-drug-related causes. Addiction 2006, 101:1771-1777.

20. McDonald SA, Hutchinson SJ, Bird SM, Mills PR, Dillon J, Bloor M, Robertson C, Donaghy M, Hayes P, Graham L, Goldberg DJ: A populationbased record linkage study of mortality in hepatitis C-diagnosed persons with or without HIV coinfection in Scotland. Stat Methods Med Res 2009, 18:271-283.

21. Hezode C, Roudot-Thoraval F, Nguyen S, Grenard P, Julien B, Zafrani ES, Pawlotsky JM, Dhumeaux D, Lotersztajn S, Mallat A: Daily cannabis smoking as a risk factor for progression of fibrosis in chronic hepatitis $\mathrm{C}$. Hepatology 2005, 42:63-71.

22. Ostapowicz G, Watson KJ, Locarnini SA, Desmond PV: Role of alcohol in the progression of liver disease caused by hepatitis $C$ virus infection. Hepatology 1998, 27:1730-1735.

23. Edlin BR, Seal KH, Lorvick J, Kral AH, Ciccarone DH, Moore LD, Lo B: Is it justifiable to withhold treatment for hepatitis $C$ from illict-drug users? N Engl J Med 2001, 345:211-215.

24. Papatheodoridis GV, Tsochatzis E, Hardtke S, Wedemeyer H: Barriers to care and treatment for patients with chronic viral hepatitis in Europe: a systematic review. Liver International 2014, doi: 10.1111/liv.12565.

25. Robaeys G, Grebely J, Mauss S, Bruggmann P, Moussalli J, De Gottardi A, Swan T, Arain A, Kautz A, Stöver H, Wedemeyer H, Schaefer M, Taylor L, Backmund M, Dalgard O, Prins M, Dore GJ, International Network on Hepatitis in Substance Users: Recommendations for the management of hepatitis C virus infection among people who inject drugs. Clin Infect Dis 2013, 57(Suppl 2):129-137.

26. Gerkens S, Natasha M, Thiry N, Hulstaert F: KCE Reports 173B Type Health Technology Assesment (HTA)., https://kce.fgov.be/fr/node/1370.

27. Husic-Selimovic A, Vukobrat-Bijedic Z, Bevanda M, Mesihovic R, Zerem E, Ahmetagic S, Trbojevic S, Verhaz A, Kezic Z, Zildzic M, Bojanic J, Petrovic J, Stojic V, Ferhatovic M, Ibrahimpasic N, Mrdjen V, Zivlak N, Barac T, BebekIvankovic H, Calkic L, Karin M, Dobrovoljski A, Rajic R, Skrbic M, Babic N, Bevanda-Glibo D: Diagnosis and treatment of chronic viral hepatitis B and C: doctrinal approach. Med Arh 2012, 66(Suppl 1):56-68. 
28. Annual report: The Czech Republic drug situation - 2011. [http://www. Drogy-info.cz/index.php/English/ annual_reports_and_other_main_resources/ annual_report_th_czech_republic_drug_situation_2011].

29. Health promotion for young prisoners. [www.adiktologie.cz/en/articles/ detail/414/4008/Health-promotion-for-young-prisoners-HPYP-]

30. Štefunkova M: Mortality and health status of former injecting drug users using low-treshold services in 1994 - follow-up study.[http://www. adiktologie.cz/en/articles/detail/414/4007/Mortality-and-health-status-offormer-injecting-drug-users-using-low-threshold-services-in-1994-follow-upstudy].

31. National handlingsplan til forebyggelse af hepatitis C. [http://www.sst.dk/ publ/Publ2007/CFF/Stofmisbrugere/Forebyggelse_hepC_stofmisbrugere.pdf].

32. Vejledning om HIV og hepatitis B og V virus. [http://www.sst.dk/publ/ Publ2013/03mar/HIVogHepBogCvejl.pdf].

33. Ministry of social affairs. [http://www.sm.ee].

34. National institute for health and welfare. [http://www.thl.fi].

35. French National Authority of Health. [http://www.has-sante.fr].

36. French Ministry of Social Affairs and Health. [http://www.sante.gouv.fr]

37. Backmund M: Leitlinien der Deutschen Gesellschaftfür Suchtmedizin (DGS e.V.): Therapie der chronischen Hepatitis $\mathrm{C}$ beiintravenös Drogengebrauchern. Suchtmed 2006, 8:129-133[http://www. dgsuchtmedizin.de/uploads/media/Leitlinien_Hepatitis_C.pdf].

38. Hepatitis-C_virus (HCV)-infektion; prophylaxe, diagnostic und therapie. [http://www.awmf.org/leitlinien/detail/l//021-012.html].

39. Hellenic center for disease control and prevention. [http://www.keelpno.gr].

40. MEGHIVÓ - Krónikus vírushepatitisek kivizsgálási és kezelési protokollja. [http://www.informed.hu/informed_site-ok/majbeteg/alapitvany/meghivokronikus-virushepatitisek-kivizsgalasi-es-kezelesi-protokollja-185078.html].

41. Health service executive. National hepatitis C strategy 2011-2014. [http:// www.hse.ie/eng/services/Publications/HealthProtection/HepCstrategy.pdf].

42. Epatite C, a chepunto siamo?. [http://www.infermieri24.it/ approfondimento/show/124/epatite-punto-siamo.html].

43. Gruppodi lavoro epatiti. [http://www.salute.gov.it/portale/temi/p2_6.jsp? lingua=italiano\&id=3275\&area=Malattie\%20infettive\&menu=vuoto].

44. Viksna L, Rozentale B, Kuse V: MEGHIIVÓ - Krónikus vírushepatitisek kivizsgálási és kezelési protokollja. [http://www.vmnvd.gov.lv/uploads/files/ 4d08c09c5b481.pdf].

45. Lietuvos Respublikos Sveikatos Apsaugos Ministras Isakymas. Del letinio virusinio $C$ hepatitio diagnostikos ir ambulatorinio gydymo kompensuojamaisiais vaistais tvarkos apraso tvirtinimo. [http://www.vlk.lt/ veikla/veiklos-sritys/kompensuojamieji-vaistai/Documents/ SAMv960 RedNr_2.pdf].

46. Halota W, Flisiak R, Boron-Kaczmarska A: Standardy leczenia wirusowych zapalen watroby typu C Rekomendacje Polskiej Grupy Ekspertów HCV 2011.[http://www.choroby-zakazne.pl/uploads/REKOMENDACJE\%2OPGE-HCV $\% 202011-1 . p d f$.

47. Carta Alba a hepatitei C in Romania. [http://www.aluzii.ro/wp-content/ uploads/2013/03/CARTA-ALBA-A-HEPATITEI-C-IN-ROMANIA.pdf].

48. Scotish intercollegiate Guidelines Network. Management of hepatitis C: a national clinical guideline. [http://www.sign.ac.uk/pdf/sign133.pdf].

49. Glasa J, Skladaný L, Holomáň J: Method Statement on Rational Therapy. [http://www.health.gov.sk/?metodicke-listy-racionalnej-farmakoterapie].

50. Maticic M, Kastelic A: National guidelines for the management of hepatitis C virus infection in drug users in Slovenia. Zdrav Vestn 2009, 78:529-539.

51. Maticic M, Brinovec V, Lesnicar G, Vidmar L, Meglic-Volkar J: Hepatitis C v Sloveniji. ISIS 1999, 8:49-51.

52. Generalitat de Catalunya, Departament de Salut. Criteris de indicacio del tractament de les hepatitis viriques. [http://www20.gencat.cat/docs/ canalsalut/Home\%20Canal\%20Salut/Professionals/Desenvolupament professional/Grups_de_treball/Consells_assessors_sobre_lus_racional_dels_ medicaments/Consell_assessor_sobre_el_tractament_farmacologic_de_les_ hepatitis_viriques/documents/arxius/crit_indica.pdf].

53. Rihtlijnbehandeling van chronischen hepatitis C virusinfectie. [http:// www.mdl.nl/uploads/240/474/7019_krt_mdl_hepatitis_c_12.pdf].

54. Croes $E_{\text {, van }}$ der Poel A: ImplemenatioevoorstelvooreenDoorbrakkproject opsporing en behandeling van hepatitis $C$ in de verslavingszorg. [http:// www.trimbos.nl/ /media/Themas/3_Preventie/Infectieziekten/Doorbraak\% 20Opsporing\%20en\%20behandeling\%20HCV\%20in\%20verslavingszorg.ashx].
55. Netherlands institute of mental health and addiction. Doorbraakproject hepatitis C in de verslavingszorg. [http://www.trimbos.nl/ /media/ Themas/3_Preventie/Infectieziekten/Factsheet\%20Doorbraak\%20Hepatitis\% 20C.ashx].

56. Department of health. Hepatitis strategy for England. [http://www.nhs.uk/ hepatitisc/SiteCollectionDocuments/pdf/hepatitis-c-strategy-for-england.pdf].

57. Department for health. Hepatitis action plan for England. [http://www nhs.uk/hepatitisc/SiteCollectionDocuments/pdf/hepatitis-c-action-plan-forengland.pdf].

58. National institute for health and care excellence. PH43 Hepatitis B and C ways to promote and offer testing:guidance. [http://www.nice.org.uk/ Search.do? $x=0 \& y=0 \&$ searchText=hepatitis\&newsearch $=$ true\&page $=1 \#$ / search/?reload].

59. Mehta SH, Genberg BL, Astemborski J, Kavasery R, Kirk GD, Vlahov D, Strathdee SA, Thomas DL: Limited uptake of hepatitis $C$ treatment among injection drug users. J Community Health 2008, 33:126-133.

60. Grebely J, Raffa JD, Ali C, Krajden M, Kerr T, Fischer B, Tyndall MW: Low uptake of treatment for hepatitis $C$ virus infection in a large communitybased study of inner city residents. J Viral Hep 2009, 16:352-358.

61. Moreno C, Deltenre P, Pawlotsky JM, Henrion J, Adler M, Mathurin P: Shortened treatment duration in treatment-naive genotype $1 \mathrm{HCV}$ patient with rapid virological response: a meta-analysis. J Hepatol 2010, 52:25-31.

62. European Association for the study of the liver: EASL clinical practice guidelines: management of hepatitis C virus infection. J Hepatol 2014, 60:392-420.

63. Lazarus JV, Sperle I, Maticic M, Wiessing L: A systematic review of hepatitis $C$ virus treatment access in people who inject drugs in the European region and the availability of medicine to treat them. BMC Infectious Diseases 2014.

64. Maticic M, Selickurincic T, Kastelic A, Poljak M, Lesnicar G, Meglic-Volkar J, Rajter M, Prah J, Baklan Z, Ciglaric M, Pancur M: A national multidisciplinary healthcare network for treatment of hepatitis $C$ in people who inject drugs in Slovenia: high enrollement, adherence and sustained virological response [Abstract]. Suchtmed 2013, 15:245.

65. Hutchinson S, Goldberg D, Brown G, Rowan N, Dillon J, Taylor A, Ahmed S: Hepatitis C strategy in Scotland. Viral Hepatitis in Practice 2012, 4(2):1-4.

66. Lindenburg CE, Lambers FA, Urbanus AT, Schinkel J, Jansen PL, Krol A, Castleen G, van Santen G, van der Berg CH, Coutinho RA, Prins M, Weeking CJ: Hepatitis $C$ testing and treatment among active drug users in Amsterdam: results from the DUTCH-C project. Eur J Gastroenterol Hepatol 2011, 23:23-31.

67. Dore GJ, Hellard M, Matthews GV, Grebely J, Haber PS, Petoumenos K, Yeung B, Marks P, van Beek I, McCaughan G, White P, French R, Rawlinson W, Lloyd AR, Kaldor JM: Effective treatment of injecting drug users with recently acquired hepatitis $\mathrm{C}$ virus infection. Gastroenterology 2010, 138:123-135.

68. Waizmann M, Ackermann G: High rates of sustained virological response in hepatitis $C$ virus-infected injection drug users receiving directly observed therapy with peginterferon alpha-2a (40KD) (PEGASYS) and once daily ribavirin. I Subst Abuse Treat 2010, 38:338-345.

69. Melin P, Chousterman M, Fontanges T, Ouzan D, Rotily M, Lang JP, Marcellin P, Cacoub P: Effectiveness of chronic hepatitis $C$ treatment in drug users in routine clinical practice: results of a prospective cohort study. Eur I GastroenterolHepatol 2010, 22:1050-1057.

70. Aspinall E, Corson S, Doyle J, Grebely J, Hutchinson SJ, Dore GJ, Goldberg DJ, Hellard ME: Peginterferon and ribavirin treatment for chronic hepatitis $C$ virus in people who inject drugs: a systematic review and meta-analysis. Clin Infect Dis 2013, 57(Suppl 2):80-89.

71. European Association for the study of the liver: EASL international consensus conference on Hepatitis C. Paris, 26-28, February 1999, consensus statement. J Hepatol 1999, 30:956-961.

72. European Association for the study of the liver: EASL clinical practice guidelines: management of hepatitis C virus infection. J Hepatol 2011 55:245-264.

73. World Health Organisation. Global policy report on the prevention and control of viral hepatitis. [http://www.who.int/topics/hepatitis].

74. Morris K: Tackling hepatitis C: a tale of two countries. Lancet 2011, 377:1227-1228

75. Maasoumy B, Manns MP: Optimal treatment with boceprevir for chronic HCV infection. Liver Int 2013, 33(Suppl 1):14-22. 
76. Hill A, Khool S, Fortunak J, Simmons B, Ford N: Minimum costs for producing Hepatitis C Direct Acting Antivirals, for use in large-scale treatment access programs in developing countries. Clin Infect Dis 2014

77. Bruggmann P, Litwin AH: Models of care for the management of hepatitis $C$ virus among people who inject drugs: one size does not fit all. Clin Infect Dis 2013, 57(Suppl 2):56-61.

78. Selin J, Hakkarainen P, Partanen A, Tammi T, Tigerstedt C: From political controversy to a technical problem? Fifteen years of opioid substitution treatment in Finland. Int J Drug Policy 2013, 24:66-72.

doi:10.1186/1471-2334-14-S6-S14

Cite this article as: Maticic et al:: Are there national strategies, plans and guidelines for the treatment of hepatitis $C$ in people who inject drugs? A survey of 33 European countries. BMC Infectious Diseases 2014

14(Suppl 6):S14.

\section{Submit your next manuscript to BioMed Central} and take full advantage of:

- Convenient online submission

- Thorough peer review

- No space constraints or color figure charges

- Immediate publication on acceptance

- Inclusion in PubMed, CAS, Scopus and Google Scholar

- Research which is freely available for redistribution

Submit your manuscript at www.biomedcentral.com/submit 